\title{
Diversity, Threats and Conservation of Herpetofauna in and around the Eastern Sinharaja
}

\author{
Thilina D. Surasinghe, Ravindra L. Jayaratne \\ Dept of Biological Sciences \\ Rajarata University, Mihintale
}

\begin{abstract}
The Eastern Sinharaja is a moist montane tropical forest that falls within the Rakwana mountain range and is $30 \mathrm{~km}^{2}$ in area. Eastern Sinharaja is the home for many threatened endemic herpetofauna where seven species of anuran amphibians three agamids, one species of gecko are known to be spot endemics where all of them are considered to be critically endangered. The eastern Sinharaja is confronting different degrees of threats due to human disturbances including deforestation and habitat destruction due to cardamom and tea cultivation, the land degradation as a result of Illegal gem mining, extraction of forest resources, illicit timber felling, collection of non-woody products, wild cardamom, medicinal plants and firewood, setting fire to the forest and grasslands and the excessive usage of pesticides in plantations. The relative abundances of the above mentioned endemic herpetofauna is significantly low. Therefore it is assumed that the population size of these species is extremely low. Having a small land area, where the primary forest vegetation is rapidly declining, the herpetofaual populations are facing an imminent threat. Therefore, immediate conservation actions are recommended. Specific attention must be paid over restoration of regarded areas with native fast growing forest species and establishment of habitat corridors to bridge the neighboring forest patches to yield space and resources to sustain the minimum viable populations. Establishment of a buffer is imperative to mediate the human impacts. The landowners must be encouraged to adopt agro-forestry practices instead of monocultures like tea/cardamom plantation, allowing establishment of small populations of herpatofauna in those agroforestry plots adjoining the reserve.
\end{abstract}

\section{Introduction}

The entire forest complex of Sinharaja is currently considered as an International Man and Biosphere (MAB) reserve. It has also been declared a UNESCO World Heritage Site (WHS) (IUCN 1987, UNESCO, 1990). Majority of its land area is lowlands. However, a small but a significant proportion spreads across higher altitudes. To be more precise, the eastern part of the Sinharaja MAB reserve falls within the sub-montane region of Sri Lanka (IUCN, 1993). The Eastern section falls within the Rakwana mountain range, which is considered a part of the Sabaragamuwa Mountains that lie in the Ratnapura district, margining Matara district. Therefore, the maximum elevation of this reserve is Hinipitigala, having a peak height of $1170 m$ (Survey Department, 2001). For instance, the peaks of Hinipitigala east and west, and llumbakanda rise up to $1168 \mathrm{~m}, 1200 \mathrm{~m}$ and $1050 \mathrm{~m}$ respectively. In fact, the elevation range of this forest, in general is, between $900 \mathrm{~m}$ to $1200 \mathrm{~m}$ (Forest Department, 2002). The areas in and around the Eastern Sinharaja are located within the Ratnapura district along with a small strip of land falling within the Matara district, for instance areas of Silverkanda. The most reputed and the main part of the Eastern Sinharaja is the Morningside proposed forest reserve. Apart from Morningside, this part of the Sinharaja MAB reserve lies in close proximity to forested regions such as Caledonia, Abbey Rock, Poddana, Lauderdale, Sooriyakanda, Silverkanda, Gongala, Kadamuduna, Kurulugala, Handapan Ella plains, Ensalwatta and Thangamalai plains (Survey Department, 1996). However, the total area of Morningside forest region is nearly 
$10 \mathrm{~km}^{2}$ (Bahir and Surasinghe, 2005). Considering the entire land area (taking into consideration all areas under natural vegetation, abandoned plantations, other state-owned unused lands, encroached lands) in and around Morningside reserve of eastern Sinharaja, the total area would be approximately $30 \mathrm{~km}^{2}$. The Eastern Sinharaja is geographically positioned between $6^{\circ} 22^{\prime}$ to $6^{\circ} 26^{\prime} \mathrm{N}$ and $80^{\circ} 31^{\prime}$ to $80^{\circ} 31^{\prime} \mathrm{E}$ (Survey Department, 2001). Topographically, the land area, unlike the lowland section, which consists of trellises of parallel ridges and valleys, is a relatively flat land and the forest area is a plateau. This section was annexed to the Sinharaja MAB reserve only in 1988 (Ministry of Lands, Land Development and the Forest Department, 1986). Nonetheless, the new boundaries are not demarcated yet and therefore the land tenure is not clear. Furthermore, the Land Reform Commission of the Sri Lankan government is also having authority on certain lands that fall within the eastern Sinharaja (Bahir and Surasinghe, 2005).

\section{Map 1: Sinharaja MAB reserve with the montane section}



A - Kudawa Conservation Centre

B - Jeep track from Kudawa Conservation Centre to Kudawa Research Station

C - Mulawella Peak

D - Kudawa Research Station

E - Gal Yen Yaya

F - Sinhagala Peak

G - Pitadeniya Conservation Centre

$\mathrm{H}$ - Pitadeniya Ticket Counter

I - Track from Mediripitiya to Pitadeniya

Conservation Centre

$\mathrm{J}$ - Kohila Aramba

K - Kekuna Ella

L - Patan-oya Ella

M - Duwili Ella (Kosmulla)

$\mathrm{N}$ - Morningside Conservation Centre

O - Natural Pool

$P$ - Duwili Ella (Morningside)

Source: Forestry and Environment Society (2005)
1 - Wathurawa- Mulawella

2 - From Kudawa Conservation Centre to Nawanda Tree

3 - From Sinhagala Trail to Gal Len Yaya

4 - Sinhagala trail from Kudawa

5 - Kohila Aamba Trail

6 - Kekuna Ella and Pata-oua Ella Trail

7 - Sinhagala Trail from Pitadeniya

8 - Duwili Ella Trail from Denuwakanda

9 - Duwili Ella Trail from MCC

10 - From Morningside to the natural pool 11 - Trail from Kosmulla via Duwili Ella to Siththara gal lena (cave) 


\section{Vegetation of the region}

This floristic region is considered as a sub-montane tropical evergreen rainforest (Surveyor General's Department, 1981; Survey Department, 1988). Nevertheless, according to the IUCN habitat assessment criteria, the vegetation type of the Eastern Sinharaja is regarded as moist montane cloud forests (Bahir and Surasinghe, 2005). However, the vegetation is transitional and is intermediate in structure and physiognomy between the lowland wet evergreen forests and tropical montane forest types (IUCN, 1993). The floristic structure and composition of Eastern Sinharaja demonstrate striking contrasts from the Sinharaja at low-elevations (Wijesinghe and Dayawansa, 2002). In contrast to the tall, thick closed canopy, high girth size and sparse undergrowth in lowland section, in the eastern Sinharaja, the canopy is low-height and the undergrowth is relatively well grown and thick. Furthermore, the canopy layer is discontinuous. Apart from the low-height vegetation, the concomitant decrease in the girth of tree trunks, gnarled crowns and the low density of trees also characterizes the Eastern Sinharaja vegetation (Gunatilleke et al., 2005). The most prominent vegetation communities are Elaeocarpus, Syzygium, Calophyllum, and Cullenia. The canopy is dominated by hill dipterocarp species like Shorea trapezifolia and $S$. gardner. The understorey vegetation is relatively dense which consists of chiefly Fahrenheitia zeylanica, Diospyros insignis, Strobilanthes spp, and Bamboo species. With respect to plants, they harbor an exceptionally diverse herbaceous and epiphytic flora including orchids, balsams, ferns, bryophytes, lichens, fungi and algae (Balasumbramanium, 1985; Gunatilleke et al., 2005). The Thangamalai plains at the extreme east of the reserve are grasslands along with the stunt woody vegetation (Wijesinghe and Dayawansa, 2002).

\section{Herpatofaunal species recorded at Eastern Sinharaja}

The Eastern Sinharaja is a home for many endemic herpatofaunal species. The reserve is well reputed as a site of point endemism. Up to date, among Sri Lankan herpatofauna, seven species of anuran amphibians, most of which belong to the genus Philautus, three agamid lizards and one gecko are known to be endemic to the Morningside reserve.

The anurans endemic to Morningside reserve are Polepedates fastigo, Philautus decoris, P. simba, P. lunatus, P. ocularis, P. papillosus, and P. poppiae. Furthermore, Philautus auratus, and $P$. silvaticusi are restricted to the Sinharaja WHS including the eastern section. Microhyla karunaratnei is recorded only from one site other than Morningside reserve, which is a part of the Eastern Sinharaja. (Fernando and Siriwardana, 1996; Dutta and Manamendra-Arachchi, 1996; Manamendra-Arachchi and Pethiyagoda, 2001; Manamendra-Arachchi and Pethiyagoda, 2005; Meegaskumbura and Manamendra-Arachchi, 2005). Apart from the amphibians, three agamids, Calotes desilvai, Ceratophora karu, C. erdeleni and one species of gecko, Cyrtodactylus subsolanus are confined to Morningside reserve and surrounding areas such as Silvakanda and Gongala (Pethiyagoda and Manamendra-Arachchi, 1998; Bahir and Maduwage, 2005; Batuwita and Bahir, 2005). Compared with other large sized montane protected areas, like Knuckles conservation area, Peak Wilderness sanctuary, Agra-Bopath sanctuary and Horton Plains National Park, the eastern Sinharaja has an exceptionally rich biodiversity and endemism per unit area (Bambaradeniya and Ranawana, 1998; IUCN/FAO, 1997). 
Table 1: Diversity and endemism of herpatofauna in some rainforests of Sri Lanka

\begin{tabular}{|c|c|c|c|c|c|c|}
\hline \multirow{2}{*}{ Protected area } & \multicolumn{2}{|c|}{$\begin{array}{c}\text { No of } \\
\text { Amphibians }\end{array}$} & \multicolumn{2}{c|}{ No of reptiles } & $\begin{array}{c}\text { Area } \\
\text { (ha) }\end{array}$ & $\begin{array}{c}\text { Forest } \\
\text { type }\end{array}$ \\
\cline { 2 - 5 } & total & $\begin{array}{c}\text { endem } \\
\text { ic }\end{array}$ & Total & endemic & & \\
\hline Agra Bopath & 08 & 05 & 01 & 01 & 6933.6 & montane \\
\hline Dediyagala & 02 & 0 & 08 & 05 & 3866.2 & lowland \\
\hline Kanneliya & 06 & 02 & 05 & 02 & 6024.5 & lowland \\
\hline Kitulgala & 31 & 19 & 08 & 03 & 265 & lowland \\
\hline Dellawa & 05 & 05 & 12 & 06 & 2236.3 & lowland \\
\hline Hakgala & 02 & 01 & 01 & 01 & 423.2 & montane \\
\hline Horton Plains & 08 & 04 & 04 & 04 & 3159.8 & montane \\
\hline Kelani valley & 04 & 01 & 08 & 03 & 2906.2 & montane \\
\hline $\begin{array}{c}\text { Peak } \\
\text { Wilderness }\end{array}$ & 11 & 08 & 12 & 09 & 5665.7 & montane \\
\hline Udawattakele & 01 & 01 & 01 & 01 & 104 & lowland \\
\hline Knuckles & 32 & 19 & 75 & 43 & 17500 & montane \\
\hline & & & & & & \\
\hline
\end{tabular}

Source: National Conservation Review (IUCN/FAO, 1997); (ManamendraArahchi and Pethiyagoda, 2005).

This section of Sinharaja not only shelters vertebrates like herpatofauna, but also invertebrates such as (Family Parathelphusidae) freshwater crabs. For instance, Ceylonthelphusa savitriae and Perbrinckia rosae are endemic freshwater crabs confined to Morningside reserve (Bahir and $\mathrm{Ng}, 2005$ ). Wijesinghe and Dayawansa (2002) have found out that Morningside reserve is higher in abundance of amphibians compared to that of lowland Sinharaja in Kudawa region whence 164 individuals were recorded in Kudawa and 575 individuals were recorded in Morningside. Flat water-retaining ground surface of Morningside reserve, especially those of grasslands, which produces permanent and semi-permanent pools, acts as ideal breeding sites for the riparian South and Southeast Asian amphibians (Zimmerman and Simberloff, 1996). With the availability of breeding sites, the abundance of these occupants also increases, resulting high abundance of amphibians species (Fernando and Perera, 1998). For example, Microhylids like and Microhyla karunaratnei are exclusively recorded from the Morningside reserve and Ramanella obscura is encountered in high frequencies in the Morningside reserve than in the lowlands. Similar explanations can be given with regard to the aquatic ranids such as Rana temporalis, $R$. aurentica and Lankanectes corrugatus that are found in large numbers in comparison to the lowland-Sinharaja.

It has been reported that tree frogs of the tropical rainforests, i.e. rhacophorids from genus Philautus and genus Polypedates, prefer to inhabit and to forage in understorey vegetation that is around $3 \mathrm{~m}$ in height (Steward and pough, 1983). Furthermore, the prevailing low temperature slows the litter decomposition and hence in Morningside there is a thick moist litter layer that creates a perfect habitat for microhylids, ranids, bufonnids and ichthyophids (Woods and Gallegos, 1970; Scott, 1976). 


\section{Conservation issues}

Despite the exceedingly small land coverage, the Eastern Sinharaja is extremely rich in biodiversity and endemism. Even though Eastern Sinharaja, especially Morningside is an important habitat for endemic herpatofauna, this part of the MAB reserve has not received conservation attention. Besides, the eastern Sinharaja is confronting threats due to unprecedented human activities.

The main reason behind the majority of the conservation problems is the lack of a governing authority. Although The Forest Department is in custody of the entire Sinharaja MAB reserve and world heritage site, no protective measures have being taken so far concerning the eastern section (Wijesinghe and Dayawansa, 2002). Despite the fact that the Forest Department incorporated the Morningside area into the Sinharaja protective network, a significant but unappraised part of Morningside is still under private ownership. Such regions are still being deforested for cultivations. A significant, but unassessed proportion of this small extent of forest belongs to the Land Reforms Commission of the government. In 2004 , this authority sought to lease out this section for the purpose of complete clearance of the forest and plantain of tea. From the viewpoint of biodiversity conservation, fortunately this destructive program was aborted (Bahir and Surasinghe, 2005).

The excessive usage of pesticides on tea plantations results in secondary problems for herpatofaunal communities with the mass killing of insect communities, which is an integral component of their food niche (Bishop and Gendron, 1998; Somaweera, 2001; Bambaradeniya, 2001). Besides, there is a tendency for bioaccumulation and biomagnification of the pesticides to occur through food webs (Moriarty, 1975; Fellers et al., 2004).

Because of the absence of physical protection and legal measures, the reserve is heavily encroached upon. Unlike the lowland section of the Sinharaja MAB reserve, the high-altitude forest has been subjected to human induced disturbances for a significant period. Part of the reserve has been replaced with tea, and most of it under-planted with cardamom (Elettaria cardamonium). Once the tea and cardamom cultivations are abandoned, the forest ecosystem does not regenerate. Instead, the sub-montane forests will be replaced by grasslands (Manamendra-Arachchi and Pethiyagoda, 1998).

The inhabitants that live in contagious villages of the reserve constantly set fire to these grasslands. This not only destroys the habitats but also directly kills the reptile and amphibian species. Moreover, burning would hinder the development of the secondary successions. In certain situations, fire spreads even into the core-forest areas causing significant degree habitat destruction. Illegal gem mining is also proving to be a severe problem. Although, the gem pits turned out to be breeding grounds for species, the land degradation accounts for modification and destruction of many other natural amphibian niches (de Rosayro, 1954).

Extraction of forest resources by the villages of the forest perimeter is happening in an alarming rate, leading to overexploitation and enhancing the extent of disturbances. Among them are tapping Kitul palms, Caryota urens, collection of various edible fruits, illicit timber felling, collection of non-woody products including mushrooms, wild cardamom, resins, oils, leaves, poles, medicinal plants and firewood (Forest Department, 1989).

Diversity, Threats and Conservation of Herpetofauna ... 


\section{Conservation actions and recommendations}

The Forest Department as the governing authority should redefine exact boundary of the Sinharaja MAB reserve and mark it with concrete posts. The disputes in the land tenure should be settled. Establishment of conservation title to this forest along with the adjacent properties and securing these lands for conservation are therefore matters of the highest priority.

All the private forestlands in the periphery of the reserve, abandoned plantations, encroached regions and currently functional plantations adjoining the reserve must come under the jurisdiction of the Forest Department. The land area under the custody of the Land Reforms Commission should also be incorporated into the land tenure of the Forest Department. It is also required to provide the physical protection to this region by means of regular patrolling by officers of the governing authority. A legal framework must be established to prevent disturbances, especially encroachments and forest-resource overexploitation and the law enforcement should be functional to take legal action against violation of rules.

Besides, as pointed out earlier, the Morningside proposed reserve is quite small in size $\left(10 \mathrm{~km}^{2}\right)$ and hence it may become incapable to host the minimum viable population of herpetofauna. Furthermore, the population size of most herpetofaunal species is significantly small (Manamendra-Arachchi and Pethiyagoda, 1998). Therefore it is recommended that surrounding forest areas and forest fragments like Silverkanda, Abbey Rock, Poddana, Sooriyakanda, Gongala, Kadamuduna, Kurulugala, Handapan Ella plains and Ensalwatta are also incorporated into the Sinharaja MAB reserve, where the total area will increase by $60 \mathrm{~km}^{2}$ from the montane region. In the case of forest fragments, it is necessary to establish forest corridors, preferably along riverine areas. Such broadening of the reserve will yield space and resources to sustain the minimum viable population of different herpetofaunal species. Moreover, by connecting different forest patches together as mentioned above, small populations of different amphibian and reptile species such as the small populations of Ceratophora species and Philautus species can disperse among the other forest patches and hence interbreed. Thence, different genetic materials from different small sub populations will recombine with each other in those reptile and amphibian species, enhancing the overall gene pool and producing a large metapoulation. Recombination of different genetic material is essential to achieve evolutionary advantages through acquiring adaptations that enhance their survival.

It is suggested that comprehensive research programs be implemented and worked out on fields of ecology, taxonomy, natural history of endemic herpetofauna, forestry and socio-economics. Such research programs can be executed with the involvement of not only the Forest Department but also other government agencies such as the Wildlife Department, the National Museum, Universities as well as non-governmental organizations. Moreover, enhancing the educational value and support provided by the reserve is also vital.

Since there are contagious villages around the Morningside, establishment of a buffer zone that coincides with the buffer zone of the entire MAB reserve is imperative (Sayer, 1991; Bandarathilake, 1992; Hall and Rodgers, 1992). Ecological restoration in terms of floristics and structure of already degraded areas of the reserve, such as abandoned tea/cardamom plantations, 
logged/firewood extracted regions, vacated chena cultivations, fire-maintained scrublands dominated by Drycranopteris lineariz and emptied gem mines by different revitalization mechanisms is essential. The reforestation and afforestation can be achieved through replantation of deforested lands with appropriate fast growing indigenous forest tree species for example, Shorea gardneri, S. trapezifolia, Palaquium spp., Homalium zelanicum, Calophyllum calaba, C. tomentosum, C. pulcherrimum, Syzygium spp., Cullenia spp., Myristica dactyloides, Cryptocarya wightiana, and Neolitsea involucrata. In rehabilitation of extremely degraded lands, as an interim measure, enrichment plantation should be implemented through the introduction of non-invasive exotic tree species such as Pinus caribaea with gradual replacement with native forest species mentioned above or as a mixed native-exotic forest plantation. (Aston et al., 1997).

The landowners of the nearby private plantations and agricultural lands must be encouraged to adopt agroforestry practices instead of monoculture and plantation agriculture. This will allow establishment of small populations of herpatofauna that can function as subpopulations, in those agroforestry plots adjacent the reserve. Later on, such small populations will interbreed with the main populations in the reserve and will create metapopulations. Such situations will enhance the genetic diversity of the gene pools of different herpatoaunal species.

Moreover, plantation of the stream reservations with appropriate riverine vegetation, for example, Shorea gardneri, Myristica dactyloides and protection of catchments and watershed areas are important conservation actions that will protect the amphibian habitats, not only of Morningside, but also in the entire MAB reserve (Gunatilleke and Gunatilleke, 1983; Ponnudurai, 1990).

It is imperative that the forest Department, as the governing authority, adopt participatory management strategies, where the general public including the local communities are considered important stakeholders in biodiversity conservation. For instance, ecotourism is a very good alternative livelihood for villages that are located around the reserve.

\section{Acknowledgment}

We wish to express our gratitude to Rohan Pethiyagoda, Kelum ManamendraArachchi and Mohomed Bahir for providing us with the necessary background information.

\section{References}

Ashton, P. M. S., S. Gamage, I. A. U. N. Gunatilleke \& C. V. S. Gunatilleke. 1997. Restoration of Sri Lankan rainforest: using Caribbean pine Pinus caribaea as a nurse for establishing late-successional tree species. Journal of Applied Ecology, 34: 915-925.

Bahir, M. M. \& K. P. Maduwage. 2005. Calotes desilvai, a new agamid lizard from Morningside Forest, Sri Lanka. Contributions to biodiversity exploration and research in Sri Lanka. The Raffles Bulletin of Zoology, Supplement No. 12: 381392. 
Bahir, M. M. \& P. K. L. Ng. 2005. Description of ten new species of freshwater crabs (Parathelphusidae: Ceylonthelphusa, Mahatha, Perbrinckia) from Sri Lanka. Contributions to Biodiversity Exploration and Research in Sri Lanka. The Raffles Bulletin of Zoology, Supplement No. 12: 47-75.

Bahir, M. M. \& A. Silva. 2005. Otocryptis nigristigma, a new species of agamid lizard from Sri Lanka. Contributions to biodiversity exploration and research in Sri Lanka. The Raffles Bulletin of Zoology, Supplement No. 12: 393-406.

Bahir, M. M. \& T. D. Surasinghe. 2005. A conservation assessment of the Sri Lankan Agamidae (reptilia: sauria). The Raffles Bulletin of Zoology, Supplement No. 12: 407-412.

Balasubramanium, S. 1985. 'Ferns of the Sinharaja forest'. Paper presented at the 'Workshop for the Preparation of a Management Plan for the Conservation of the Sinharaja Forest', Forest Department, Colombo.

Bambaradeniya, C. N. B. \& K. B. Ranawana. 1998. 'Some amphibians observed in three mountain forests of Sri Lanka', in Biology and conservation of the amphibians, reptiles and their habitats in South Asia, 108-113, de Silva, A. (ed.) Peradeniya : Amphibian and Reptile Research Organization of Sri Lanka.

Bambaradeniya, C. N. B. 2001. Rice fields : An important man - made habitat for amphibians. Lyriocephalus, 4: 57-64.

Bandarathilake, H. M. 1997. Buffer zone development in Sinharaja world heritage forest, Sri Lanka. Paper presented at the 'Fourth World Congress on National Parks and Protected Areas', Toronto, Canada.

Batuwita, S. \& M. M. Bahir. 2005. Description of five new species of Cyrtodactylus (Reptilia: Gekko nidae) from Sri Lanka. Contributions to biodiversity exploration and research in Sri Lanka. The Raffles Bulletin of Zoology, Supplement No. 12: 169-198.

Bishop, C. A. \& A. D. Gendron. 1998. Reptiles and amphibians shy and sensitive vertebrates of the great lake basin and St. Lawrence river. Environmental monitoring and assessment 53: 225-244.

de Rosayro, R. A. 1954. A reconnaissance of Sinharaja rainforest. Ceylon forester 1: 15-28.

de Zoysa, N. D. \& R. Raheam. 1990. Sinharaja: A rainforest in Sri Lanka. March for conservation, Colombo.

Dutta, K. D. and K. Manamendra - Arachchi. 1996. The Amphibian fauna of Sri Lanka. Wildlife Heritage Thrust of Sri Lanka.

Fellers, G. M. L. L. McConnell, D. Pratt and S. Datta. 2004. Pesticides in mountain yellow-legged frogs (Rana muscosa) from the Sierra Nevada mountains of California, USA. Environmental Toxicology and Chemistry 23: 2170-2177. 
Fernando, P. \& M. Siriwardhane. 1996. Microhyla karunaratnei (Anura: Microhylidae), a new species of frog endemic to Sri Lanka. Journal of South Asian Natural History 2: 135-142.

Fernando, P. \& R. Perara. 1998. Amphibia of the Sinharaja rainforest. in Biology and Conservation of the amphibians, reptiles and their habitats in South Asia. 118-125, A. de Silva, (ed.) Peradeniya : Amphibian and Reptile Research Organization of Sri Lanka.

Forest Department. 1989. Socio-economic reports for nine villages around Sinharaja Forest, Colombo : Ministry of Environment and Natural Resources.

Forest Department. 2002. Sinharaja our heritage, Colombo : Forest Department.

Forestry and Environment Society. 2005. Sinharaja rainforest trail map. Available Online : http://www.environmentlanka.com/biodiv/Sinharaja_trailMap.html

Gunathilleke, C. V. S. \& I. A. U. N. Gunathilleke. 1981. The floristic composition of Sinharaja, a rainforest in Sri Lanka, with special reference to endemics and dipterocarps. The Malayan Forester 44 : 35-48.

Gunathilleke, C. V. S. \& I. A. U. N. Gunathilleke. 1983. A forestry case study of Sinharaja rainforest in Sri Lanka in Forest and Watershed Development and Conservation in Asia and the Pacific. 289-358, L. S. Hamilton (ed.) Boulder: Westernview Press.

Gunatilleke, I. A. U. N., C. V. S. Gunatilleke \& M. A. A. B. Dilhan, 2005. Plant biogeography and conservation of the south-western hill forests of Sri Lanka. Contributions to biodiversity exploration and research in Sri Lanka. The Raffles Bulletin of Zoology, Supplement No. 12: 9-22.

Hall, B, J. \& Rodgers, W. A. 1992. Buffers at boundary: Network paper, Road Development and Forestry Network. UK: Overseas Development Institute.

IUCN. 1987. Sri Lanka World Heritage Nomination. Summary, Switzerland:IUCN.

IUCN. 1993. Management Plan for the conservation of Sinharaja forest (Phase iii), Colombo: IUCN-Sri Lanka.

IUCN/FAO. 1997. Designing an optimum protected areas system for Sri Lanka's natural forest conservation. Vol: 2 . Colombo :Forest Department.

Manamendra-Arachchi, K. \& R. Pethiyagoda. 2001. Polepedates fastigo, a new tree frog (Ranidae: Rhacophoriidae) from Sri Lanka. Journal of South Asian Natural History 5: 191-199.

Manamendra-Arachchi, K. \& R. Pethiyagoda. 2005. The Sri Lankan shrub-frogs of the genus Philautus Gistel, 1848 (Ranidae: Rhacophorinae), with description of 27 new species. Contributions to biodiversity exploration and research in Sri Lanka. The Raffles Bulletin of Zoology, Supplement No. 12: 163-303.

Meegaskumbura, M. \& K. Manamendra-Arachchi. 2005. Montane isolates and cryptic diversity: description of eight new species of shrub frogs (Ranidae: Rhacophorinae: Philautus) from Sri Lanka. Contributions to biodiversity 
exploration and research in Sri Lanka. The Raffles Bulletin of Zoology, Supplement No. 12: 305-338.

Ministry of Land, Land Development \& the Forest Department. 1986. conservation plan for the Sinharaja Forest, Switzerland: WWF.

Moriarty, F. 1975. Organochlorine Insecticides; persistent organic pollutants, London: Academic Press.

Ponnudurai, D. K. 1981. Effect of logging on some hydrological parameters of a wet zonal Forest in Sri Lanka, M. Sc. Thesis, Postgraduate Institute of Agriculture.

Pethiyagoda, R. \& K. Manamendra-Archchi, 1998. A revision of the endemic Sri Lankan agamid lizard genus Ceratophora, Gray, 1835, with description of two new species. Journal of South Asian Natural History 3: 1-50.

Sayer, J. 1991. Rainforest bufferzone, Switzerland : IUCN.

Steward, M. M. \& F. H. Pough. 1983. Population density of tropical forest frogs: relation to retreat sites. Science 221: 571-572.

Scott, N. J. 1976. The abundance and diversity of the herpatofaunas of tropical forest litter. Biotropica 8: 41-58.

Somaweera, R. 2001. Biodiversity survey on the herpetofauna of the Manikdena archeological site, Dambulla, Sri Lanka. Abstracts of the young environment symposium, University of Sri Jayawardenapura and Young Biologists' Association of Sri Lanka.

Surveyor General's Department. 1981. Forest map of Sri Lanka based on landsat, Colombo: Department of Surveys.

Survey Department. 1988. National Atlas of Sri Lanka, Colombo: Department of Surveys.

Survey Department. 2001. Sri Lanka 1:50 000, Rakwana, Sheet no 81, Colombo: Department of Surveys.

Survey Department. 1996. Road map of Sri Lanka, Colombo: Department of Surveys.

UNESCO. 1990. The world heritage - a legacy for all, Paris:UNESCO.

Wijesinghe, M. R. \& P. N. Dayawansa. 2002. The amphibian fauna at two altitudes in the Sinharaja rainforest, Sri Lanka. Herpetological Journal 12: 175178.

Woods, F. W. \& C. M. Galleogos. 1970. Litter accumulation in selected forests of the Republic of Panama. Biotropica 2: 46-50.

Zimmerman, B. L. \& D. Simberloff. 1996. An historical interpretation of habitat use by frogs in a Central Amazonian forest. Journal of Biogeography 23: 27-46. 